\title{
THE NEW UNDERGRADUATE COURSE ON EARTH SCIENCES AT UNICAMP AND THE GEOLOGICAL EDUCATION IN THE NEAR FUTURE IN BRAZIL
}

\section{BERNARDINO RIBEIRO FIGUEIREDO}

\begin{abstract}
The most recent undergraduate course on Earth Sciences in Brazil started at Unicamp in 1998. This course is devoted to generating new graduates in geology, geography as well as geography teachers. During the last 20 years, the Institute of Geosciences at Unicamp has been dedicated to research and advanced graduate courses in several scientific areas. The present paper contains a description of part of the undergraduate program, specifically that which is more related to Geology. The course program benefited to a large extent from the intense discussions on geological education that took place all over the world in the last decades. This new course is attuned to the most modern experiences in geological education, by adopting the Earth System Science as the unifying approach of the disciplines. However, it differs from the traditional courses in the sense that human and social sciences have a greater weight in the curriculum (11\% of course length is dedicated to social sciences and English and, 24\% to mathematics, physics, chemistry and biology). Hopefully, that may lead to produce more capable professionals to work in multidisciplinary groups, which will be increasingly required in the near future. Following the recently approved Law of Guidelines and Basis for Education in Brazil (Lei de Diretrizes e Bases para a Educafdo - LDB), an increasing flexibility of university curricula and shorter undergraduate courses are being stimulated by the new policies for higher education in Brazil, which may induce further improvement of Unicamp's Earth Sciences program.
\end{abstract}

Keywords Geological education, Earth System, curricula guidelines, Unicamp

INTRODUCTION A new undergraduate course on Earth Sciences started at Unicamp in 1998. This course has classes both during the day and at night and it is devoted to generating geologists and geographers as well as teachers of geography. Although the course is in the Institute of Geosciences (IG), lectures are also given by faculty members from the Institute of Philosophy and Human Sciences, Agricultural Engineering Faculty, Faculty of Education and other departments of Unicamp. During the past 20 years the Institute of Geosciences has been dedicated mainly to research and to M.Sc. and $\mathrm{Ph} . \mathrm{D}$. programs in several scientific areas, namely, Mineral Resources Management and Policy, Metallogenesis and Geochemistry, Petroleum Geology, Geosciences Education and Science and Technology Policy. The IG-Unicamp was the only academic unit, among ca. 20 institutions, which deals with geosciences in Brazil that did not have undergraduate courses on Geology.

The new undergraduate course program benefited to a large extent of the intense discussions on geological education that took place all over the world in the last decades. The present paper concentrates only on the description of the original proposal of the Geology course and on the its foreseeable further development.

OBJECTIVE AND CONTENT OF THE NEW EARTH SCIENCE EDUCATION PROGRAM Planned for a minimum of 3900 hours, this program is oriented to educate new geologists for the new world of the $21^{\text {st }}$ century, i.e., those who have the skills to contribute to the economic and social development of the country and to solve emergent problems affecting humankind in a such way that the principles of sustainable life in our planet are taken into account.

In order to achieve these goals, the following aspects have been incorporated in the course program:

(i) Historical, epistemological and methodological elements may be emphasized in geological education to make clear what changes in research and professional activities are being induced by the new scientific \& technological paradigms;

(ii) Subjects related to social sciences on economics, sociology, geography, Laws and public policies are part of the curriculum as well as concepts of administration of both public and private sectors and learning of foreign languages specially English;

(iii) Fieldwork is emphasized throughout the course, as well as the assessment of the new techniques of GIS, remote sensing, 3Dmapping and quantification methods;

(iv) The geology curriculum adopts the Earth System Science as the integrating element of other subjects and therefore great value is given to literacy in basic sciences, applied mathematics and the use of computers;

(v) Enhancing the communication of Geology with other natural sciences and with social sciences is envisaged to produce a new geologist more capable of working in multidisciplinary teams, to reach leadership positions or to follow a more perceptive academic career than the professionals in the past.

* Institute de Geociências, Universidade Estadual de Campinas E-mail: berna@ige.unicamp.br (vi) Extra-class activities such participation in research, training programs in industry and oriented dissertation at the end of the course will encourage the students to choose their scientific areas of interest and to be active in seeking geological literacy on their own, hence preparing themselves for a permanent education life.

The Unicamp Earth Sciences course consists of a common core of disciplines (Nucleo Comum) in the first three semesters, at the end of which the students should choose between Geology and Geography. The students of Geology will follow additional seven semester courses. The program includes the compulsory subjects as shown in Table 1, plus a minimum of two optional subjects and a final monograph.

The new curriculum dedicates $11 \%$ of its length to social sciences (e.g. economics, administration, legislation, sociology of science) and English; $24 \%$ to mathematics, physics, chemistry and biology, $35 \%$ to basic geology and other disciplines like soil sciences and climatology and, $30 \%$ to applied geology. Among the current optional disciplines are those oriented to explore more deeply some contents on environmental sciences, mineral and fuel resources, geophysics (seismic), geostatistics, petrology, geochemistry and others as well as disciplines of other undergraduate courses at Unicamp, including those on geography.

THE EARTH SYSTEM SCIENCE This new course is attuned to the most modern experiences in geological education, adopting the Earth System Science as the unifying approach of the disciplines. The Earth System Science represents a new approach of Geology, which is now required to solve regional and global problems, some of which are derived from the economic development of the world in the past and some required by the current technological paradigm led by the electronic communication revolution.

The Earth System Science states that the study object of Geology is the interface of Earth spheres (geosphere, biosphere,

hydrosphere, atmosphere and anthroposphere) and not exclusively the geosphere or any other isolated sphere. At the same time, the Earth System Science extends the Actualism principle of the modern geology, according to which the knowledge of present phenomena was the clue to understand those of the past, suggesting that the knowledge of natural processes operating from the past to present may be used to understand, predict and quantify geological phenomena in the future. Many authors as Mayer $(1991,1995)$ discuss the role of the Earth System Science in the various research and education levels among others. These topics were brought up for discussion during the 37 Brazilian Geological Congress held in Sao Paulo 1992 by Figueiredo and Susslick (1992) and Da Costa and Inda (1992).

Very rapid changes in the technological basis of the world economic development led to a severe crisis of all-traditional sciences and professions including geology and some geological specialization. The crisis of Geology has been a recurrent subject of debate in Brazil since the ' 80 s as it was in many other countries. Deep concern about the limits of the non-renewable resources, global climate changes, environmental and geological hazards, water supply and land use

(Unicamp), P.O. Box 6152, 13083-330, Campinas, Brazil 
Table 1 - The curriculum of the undergraduate program in Geology at Unicamp

\begin{tabular}{|c|c|c|c|c|c|}
\hline \multicolumn{6}{|c|}{ Common Core for Geology and Geography } \\
\hline \multicolumn{2}{|c|}{ Term 1} & \multicolumn{2}{|c|}{ Term 2 } & \multicolumn{2}{|c|}{ Term 3 } \\
\hline \multicolumn{2}{|c|}{ Science, Technology and Soctety (3) } & \multicolumn{2}{|c|}{ Science Theories and Methods (3) } & \multicolumn{2}{|c|}{ History of Economics Theories (3) } \\
\hline \multicolumn{2}{|c|}{ Earth System Scjence I (6) } & \multicolumn{2}{|c|}{ Earth System Science II (6) } & \multicolumn{2}{|c|}{ Geomorphology (4) } \\
\hline \multirow{2}{*}{\multicolumn{2}{|c|}{ Biology $(3)$}} & \multicolumn{2}{|c|}{ Biogeography (3) } & & \\
\hline & & \multicolumn{2}{|c|}{ Mathematics for Earth Sciences (4) } & \multicolumn{2}{|c|}{ Statistics for Earth Sciences (4) } \\
\hline \multicolumn{2}{|c|}{$\begin{array}{l}\text { Drawing, Topography and Graphic } \\
\text { Computer Systems (4) }\end{array}$} & Climat & $\log y(4)$ & \multicolumn{2}{|c|}{ Pedology (4) } \\
\hline \multicolumn{2}{|c|}{ Space Organization (3) } & \multicolumn{2}{|c|}{ Thematic Cartography (4) } & \multirow{2}{*}{\multicolumn{2}{|c|}{$\frac{\text { Field Work (4) }}{\text { Physics for Human and Earth Sciences (4) }}$}} \\
\hline \multicolumn{2}{|c|}{ Chemistry (4) } & & & & \\
\hline (23) & & \multicolumn{2}{|c|}{ (24) } & \multicolumn{2}{|c|}{$(23)$} \\
\hline \multicolumn{6}{|c|}{ Geology Track - Compulsory Subjects } \\
\hline \multicolumn{2}{|c|}{ Term 4} & \multicolumn{2}{|c|}{ Term 5} & \multicolumn{2}{|c|}{ Term 6 } \\
\hline \multicolumn{2}{|c|}{ Natural Resources Legislation (2) } & \multicolumn{2}{|c|}{$\begin{array}{l}\text { Mining and Environmental Management } \\
\text { (2) }\end{array}$} & \multicolumn{2}{|c|}{$\begin{array}{c}\text { Economics of Mineral and Energy } \\
\text { Resources (2) }\end{array}$} \\
\hline \multicolumn{2}{|l|}{ Paleontology (4) } & \multicolumn{2}{|c|}{ Sedimentary Petrography (4) } & & \\
\hline General Physics I & & General Pl & ysics III (4) & & General Physics IV (4) \\
\hline Experimental Physics & & Experimental & Physics III (2) & & sperimental Physics IV (2) \\
\hline Mineralogy $(6)$ & & Igneous and Metamo & rphic Petrography (6) & & Structural Geology $(6)$ \\
\hline Physical Chemistry & & Geoche & nistry (4) & & Petrology $(6)$ \\
\hline Analytical and Vectorial Ge & $\operatorname{try}(4)$ & Sedimen & $\operatorname{ology}(4)$ & & nalytical Geochemistry (4) \\
\hline Matemathics (Geolog) & & Engli & hI (4) & & English II (4) \\
\hline$(30)$ & & & 0) & & (28) \\
\hline Term 7 & & Term 8 & Term 9 & & Term 10 \\
\hline $\begin{array}{l}\text { History and Theory of } \\
\text { Organizations (2) }\end{array}$ & Histor & Natural Sciences (2) & Mineral Explorat & $n(6)$ & Final Dissertation (12) \\
\hline Geophysics (4) & & otectonics (4) & $\begin{array}{l}\text { Mining Geolog } \\
\text { Extraction and Benef }\end{array}$ & $\begin{array}{l}\text { Ore } \\
\text { iation (4) }\end{array}$ & \\
\hline Stratigraphy (4) & Soil a & Rock Mechanjes (4) & Urban Geolog & & \\
\hline $\begin{array}{l}\text { Historical Geology and } \\
\text { Geology of Brazil (6) }\end{array}$ & & mic Geology (6) & Geotechnics & & \\
\hline & & Irogeology (4) & Field Geology & & \\
\hline $\begin{array}{l}\text { Remote Sensing and } \\
\text { Photogeology (6) }\end{array}$ & $\mathrm{Ge}$ & $\begin{array}{l}\text { phic Information } \\
\text { Systems (4) }\end{array}$ & & & \\
\hline Filed Geology I (6) & Geolo & $\begin{array}{l}\text { ff Energy Resources } \\
\text { (4) }\end{array}$ & & & \\
\hline (28) & & $(28)$ & (24) & & (12) \\
\hline
\end{tabular}

(*) amount of weekly hours corresponding to number of credits

planning among others were at the center of these debates and were put on top of the list of the great challenges for geosciences.

These new concepts of the Earth System Science are the basis of ongoing reforms of geology curricula around the world and proved to be useful not only to strengthen geological education but also to open new avenues for scientific research especially in industrialized countries.

THE SOCIAL SCIENCES ROLE IN GEOLOGICAL EDUCATION The present course differs from the traditional ones in the sense that human and social sciences have a greater weight in the curriculum. It is expected that this broader view of the world may lead to formation of professionals more capable of communicating to other professionals, including politicians, lawyers and business managers. Geology achieved the status of modern science through the work of James Hutton and Charles Lyell two hundred years ago. Since then, like the other scientific areas, geology has been going through a process of subdivision and specialization. This process brought some advantages to science in terms of a work division among specialists but also induced the closure and fragmentation of knowledge. According to Morin (1996) the same specialization process made the specialist unaware of everything that does not concern his discipline, and condemned the non-specialist to prematurely resign to reflect about the world, life and society. In this way, the development of knowledge itself created a resignation to ignorance and, the development of science finally resulted in enhancing unconsciousness. To overcome this sad reality the author suggests that a communication bridge must be built between natural and social sciences. Philosophy and anthroposocial sciences can no longer develop without the new achievements of physics and biology. On the other hand, it is now impossible to conceive the transformations of nature without considering the demographic, social, economic and political ongoing processes on a worldwide or regional basis.

Many authors have spoken in favor of incorporating some subjects from human sciences (philosophy, history, economics, law, administration) in connection with a variety of fields of applied geosciences. That is especially important when the relationships between, natural spheres and anthroposphere, i.e. nature and society, are considered. From the ethical point of view, that does not involve putting value on human life alone because, as Edgard Morin argues, it is only possible to show respect for human life if we respect life in general. Fyfe (1990) claims that the current anthropocentric orientation of science needs to be changed into an ecocentric one addressing both societal and environmental concerns. 
Nevertheless, educational programs in Geology encompassing communication between natural sciences and human sciences are still rare in the world. Coincidentally, the Unicamp Earth Sciences program is based at the IG-Unicamp, a very singular institution, founded by Professor Amilcar Herrera, in 1979, where geologists, engineers, social scientists, geographers, educators and other specialists work together or, at least, are learning to work together.

In summary, a better understanding of social and environmental aspects related to geoscientific work can only be achieved by enhancing communication between natural and social sciences. In this way, the cooperation between geology and geography, the latter, a social science that deals with space and landscape concepts, can be very important. The new geologists are being convinced that the global and regional problems emerging from the current economic development can only be solved by multidisciplinary work that includes the important contribution of Geology. It is foreseeable that multidisciplinary working groups, in which the geologists can be participants and even leaders, will be increasingly required in the near future.

THE FIRST YEARS EXPERIENCE The Unicamp's Earth Sciences course started in 1998 and it is, of course, to early to evaluate the program achievements. However, there are two or three points that deserve to be recalled briefly.

In Brazil, students must pass an exam to enter University and often the number of candidates exceeds the available places. The candidate/ place ratios can be very high for some very competitive courses like medicine, biology and computer science, but are traditionally low for geology and geography courses. So, just to give some figures, the candidate/place ratios of Earth Sciences course at Unicamp have evolved as following: 6.1 in 1998, 7.7 in 1999 and, 9.0 in 2000.

Another aspect that deserves comment is related to the cooperation efforts required for multidisciplinary and transdisciplinary work among professors and students. As many people say, multidisciplinary work is easy to talk about but difficult to accomplish. How to teach the students to relate contents from different subjects and specialization if the professors do not practice it themselves? Albeit very hard to do, there have nevertheless been some opportunities for cooperation and changing attitudes. For the first time in 1999, a field work course was given by a group of six teachers of geology and geography working together with a group of students for a period of 8 days in the field. That was a remarkable first-hand experience of communication between two different languages and practices that shows that good results can be achieved given time and good will.

Finally, it is important to recall that the separation of the natural from social sciences is a very common practice in secondary and high school. The students enter university with a vision that social science, on the one hand, and matemathics, physics and chemistry, on the other, are incompatible subjects. Some of them believe that those who like human sciences should not need to "suffer" by learning "hard sciences" and, those who like natural and exact sciences do not need to read so much "philosophy". To overcome these mutual prejudices, words and speeches are not enough. It is essential that the professors act coherently, i.e., geologists have to be less ignorant about social processes and geographers more interested in natural phenomena. The ideal student for Unicamp's Earth Sciences course would be those who like history as much as physics, chemistry as much as literature and so on. In other words, those students who cannot decide between the natural and human sciences at the end of high school because they feel comfortable with all subjects and enjoy everything.

THE NEW GEOLOGY CURRICULA IN BRAZIL Higher education in Brazil has been linked to the various resolutions that fixed the "minimum curricula" for all professional areas in the sixties and seventies. However, according to the new Law of Guidelines and Basis for Education in Brazil (Lei de Diretrizes e Bases para a Educação, no. 9394 of 20/12/1996), all the minimum curricula and former resolutions became invalid. To replace them and regulate the current and future courses, the Ministry of Education (Edital no. 04/97 of 10/ 12/1997) and the National Education Council are elaborating the new Curricula Guidelines (Diretrizes Curriculares) for all professional areas and courses. Universities as well as scientific and professional organizations have been invited to send their opinions on the future Curricula Guidelines and on related subjects such as the desirable professional profiles, and societal demands in each area, integration of undergraduate and graduate courses and evaluation procedures. The Edital 04/97 invited the faculties to think about the "Essential Contents" which would be mandatory for all courses and to leave a substantial part of course contents to be freely formulated by the Universities in response to their abilities and regional requirements. All this points to an increasing flexibility of university curricula (less compulsory classroom activities), shorter undergraduate courses (minimum of $3000 \mathrm{~h}$ instead of the current 3600 hours for Geology courses) and adoption of permanent education practice.

The new Curricula Guidelines for higher education in Brazil emphasize the necessity of enhancing the intellectual autonomy of the students. This is thought to be achieved by shortening the time of classroom activities in favor of various complementary activities in the field, laboratory, Internet and library research. It is said that the students have to learn how to learn as the only way to overcome the rapid process of obsolescence in science and technology.

The structure of the new courses will include basic scientific and geological science subjects (2/3) and professionally oriented or applied geological subjects $(1 / 3)$. Geological mapping and a final monograph would be compulsory.

Among the subjects of the basic science unit it is suggested that about $10 \%$ of the time be dedicated to social science subjects including Law and English. Some courses are considering the possibility of distributing the various topics of scientific subjects (Maths, Physics, Chemistry and Biology) throughout the course instead of having them all together in the beginning of the course. The advantage of this is to establish more concrete and less abstract links between basic sciences and the different fields of applied geology.

The contents of the basic geology unit are exemplified by a list of traditional subjects such as mineralogy, historical geology, stratigraphy and so on. However, the new regulations are likely to contain definitions of the essential contents of geology that all courses may assume and translate in terms of disciplines on their own. For instance, at Unicamp the academics agreed that all geological courses in Brazil have to cover the following geological contents:

7 - Earth system dynamics: Studies of the structure and functioning of the Earth, from its interior, represented by mantle and crust, to the surface. Characteristics of the external spheres of the Earth, pedosphere, hydrosphere, atmosphere and biosphere and their interaction with the geosphere. Fieldwork and the use of some modern tools such as geophysics, remote sensing, GIS and others would be mandatory.

2 - Rock-forming processes: Integrated studies of igneous, metamorphic and sedimentary rocks and related resources. Petrographic and petrologic studies, lithogeochemistry, structural geology and field geology.

3 - Geochemical processes: Studies of chemical processes active in the interior and on the surface of the Earth taking advantage of the acquired information on cosmochemistry, chemical composition of Earth, surface and near-surface geochemistry, environmental geochemistry and analytical techniques.

4 - Historic geology and Brazilian geology: Studies of the major geologic-tectonic units of Earth Crust, stratigraphy, paleontology, geochronology and Brazilian geology.

5 - Physical resources of the Earth: Origin and use of mineral, energy and water resources, and soil and hydrographic basin management.

It is very probable that the National Education Council considers that the contents of the basic science and of the basic geology units will not exceed $2 / 3$ of the length of the course. That means that about $1 / 3$ of the course will be dedicated to disciplines oriented to strengthen the students' knowledge in specific areas of applied geology. Those disciplines should be freely chosen and organized in specialization modules such as regional geology, environmental geology, ore deposits and mineral exploration, petroleum geology, hydrogeology, engineering geology, marine geology, geological education and others.

Those specialization modules will vary from one university to another and will mirror the composition of the academic staff, history of the institutions and regional, social and economic environments. It would be appropriate that mechanisms are created to make it easier for 
the students to attend courses in other institutions in case they choose a specialization module not available in their own departments.

A great value is being credited to complementary (extra-classes) activities oriented to improve independent and autonomous search of knowledge by the students. Among these complementary activities geological mapping and an end-of-course monograph are being proposed as compulsory.

CONCLUDING REMARKS The new Earth Sciences course at Unicamp is based on enhanced science literacy and communication between geosciences and geographic and other human sciences. Its success clearly depends on foreseeable changes in attitude of the academic members. Geologists must understand better the ongoing social processes that strongly interfere with nature and, on the other hand, geographers and social scientists must weigh up the important achievements of biology, chemistry, physics and geology in their research and teaching.

Coincidently, the conceptual framework of the new course and the forthcoming educational reforms in Brazil point to same direction. The universities will be freer to formulate higher education curricula than in the past. Enhanced curriculum flexibility and university autonomy may bring more objectivity, originality and excellence to the future educational programs on geosciences in Brazil.

Among the various proposals of curricula guidelines for different scientific areas and professions which are available in the Internet [www. mec.gov.br/sesu/diretriz/diretriz.htm], the best formulated were produced by the best-organized academic groups. The geoscientific community in Brazil needs to be more active and unified in order to face the great challenges of this new century.

\section{References}

Da Costa L.A.M. \& Inda H.A.V. 1992. Fundamentos da Geologia Pos-Moderna, CPRM, Serie Sinopses, DGH/S/A004-92, 8 p

Figueiredo B.R. \& Suslick S.B.I 992. Ciencia do Sistema Terra: uma nova abordagem da Geociências. In: SBG, Congr. Bras, de Geol., 37, Sao Paulo, Apresentafao no Seminario Geologia: O Profissional e a Ciencia (umpublished).

Fyfe W.S. 1990. The International Geosphere/Biosphere Programme and Global Change: An anthropocentric or an ecocentric future? A personal view. Episodes, 13:100-102

Mayer V.J. 1991. Earth-systems science - a planetary perspective. The Science Teacher, 58:31-36
Mayer V.J. 1995. Using the Earth system for integrating the science curriculum. Science Education, 79:375-391.

Morin E. 1996. Ciencia com Consciencia. Rio de Janeiro, Bertrand Brasil, 336p.

Contribution IGC-076

Received February 24, 2000 Accepted for publication April 30, 2000 